Asian-Australasian Journal of Food Safety and Security

ISSN 2523-1073 (Print) 2523-2983 (Online)

www.ebupress.com/journal/aajfss

\title{
Article \\ Evaluation of commonly used fertilizers, fish and poultry feeds as potential sources of heavy metals contamination in food
}

\author{
Md. Sanaullah Sarker, Quazi Forhad Quadir , Md. Zakir Hossen, Touhida Nazneen and Atiqur Rahman \\ Department of Agricultural Chemistry, Bangladesh Agricultural University, Mymensingh, Bangladesh
}

*Corresponding author: Professor Dr. Quazi Forhad Quadir, Department of Agricultural Chemistry, Bangladesh Agricultural University, Mymensingh, Bangladesh. Phone: +8801911 247736; Fax: +880 91 61510; E-mail: qfq@bau.edu.bd

Received: 07 November 2017/Accepted: 20 November 2017/ Published: 21 November 2017

\begin{abstract}
An experiment was conducted at the Department of Agricultural Chemistry, BAU to assess the heavy metal status in different feed and fertilizer samples collected from Sadar and Trisal upazilas of Mymensingh district. The feed samples included poultry and fish feeds, whereas, fertilizer samples included DAP, TSP, MOP, gypsum and zinc sulphate $\left(\mathrm{ZnSO}_{4}\right)$. AAS analysis of $\mathrm{Cd}, \mathrm{Cr}$ and $\mathrm{Pb}$ showed variable levels of contamination in the fertilizer and feed samples. In case of feed samples, $\mathrm{Cd}$, and $\mathrm{Pb}$ contents in fish feed collected from Sadar upazila was 0.159 and $3.581 \mathrm{mg} \mathrm{kg}^{-1}$, respectively and that of Trisal upazila was 0.441 and $153.824 \mathrm{mg} \mathrm{kg}^{-1}$, respectively. The content of Cd was $0.008 \mathrm{mg} \mathrm{kg}^{-1}$ in poultry feed but in fish feed it was 0.441 $\mathrm{mg} \mathrm{kg}^{-1}$. The $\mathrm{Cr}$ content in both poultry and fish feeds collected from Sadar and Trisal upazilas were below the detection level. In general, heavy metals contaminations were higher in different fish feed samples compared to that of poultry feed samples, especially in samples from Trisal upazila.The Cd contents in DAP, TSP, MoP, gypsum and $\mathrm{ZnSO}_{4}$ collected from Sadar upazila were $1.560,14.749,0.137,0.906$ and $10.312 \mathrm{mg} \mathrm{kg}^{-1}$, respectively, and that of Trisal upazila were $1.780,15.662,3.988,1.180$ and $3.165 \mathrm{mg} \mathrm{kg}^{-1}$, respectively. The $\mathrm{Cr}$ contents in DAP, TSP, MoP, gypsum and $\mathrm{ZnSO}_{4}$ collected from Sadar upazila were 60.392, 206.667, 15.882, 24.314 and $11.373 \mathrm{mg} \mathrm{kg}^{-1}$, respectively. Whereas, mean $\mathrm{Cr}$ concentrations DAP, TSP, MoP and gypsum from Trisal upazila were 54.118, 168.431, 16.078 and $26.863 \mathrm{mgkg}^{-1}$, respectively. However, in $\mathrm{ZnSO}_{4} \mathrm{Cr}$ was below the detection limit. Again, $\mathrm{Pb}$ contents in DAP, TSP, MoP, Gypsum and $\mathrm{ZnSO}_{4}$ collected from Sadar upazila were $12.633,45.729,33.586,13.319$ and $30.014 \mathrm{mg} \mathrm{kg}^{-1}$, respectively, and that of Trisal upazila were 4.062, $46.919,101.205,21.681$ and $6.676 \mathrm{mg} \mathrm{kg}^{-1}$, respectively. In general, heavy metal contamination levels in different fertilizer samples collected from Mymensingh Sadar were higher compared to that of Trisal upazila. The results showed that despite the close proximity of the market locations, heavy metal contents may vary in fertilizer and feed samples indicating various supply chains of these essential inputs are in place and calls for greater degree of quality monitoring from the government point of view.
\end{abstract}

Keywords: heavy metal contamination; poultry and fish feeds; fertilizers; Bangladesh

\section{Introduction}

In most developing countries like Bangladesh, attempts to increase food production and consumption are undermined by rapid population growth, migration from rural to urban areas and widespread land degradation. Population pressure continues to place a severe burden on productive capacity in the most developing countries like ours. However, the increasing population of the country needs an urgent supply of food for balancing the growing population with an increased food production (Nabulo et al., 2012). Nowadays, our country faces acute population pressure. But adopting modern agricultural practices, our country ensures the food demand of growing population in spite of having shortage of land. Bangladesh has managed to triple its rice production since its independence. Adoption of modern technologies accompanied by increased food 
production may facilitate metal contamination in our food chain. Heavy metal contamination may occur due to factors including irrigation with contaminated water, the addition of fertilizers which may be contaminated with trace and heavy metals and metal based pesticides, industrial emissions, transportation, post harvesting process, storage and/or sale (Ali et al., 2013). Such heavy metal contaminations of food have a long term effect on our heath as well as our next generation.

Again, heavy metals contaminate the food at various stages along the food production line. Due to depletion of soil nutrients, agricultural application of chemical fertilizers is increasing globally. As human population continues to increase, putting pressure on food production systems, mainly crop and livestock production, the increase in the demand for food also raises but soil fertility deteriorates with time. This has led to substantial increase in application of plant nutrients, including inorganic fertilizers in the last 50 years to increase food production in order to satisfy human population demand (Ashraf, 2006). More than 30 million metric tons of phosphate fertilizers are annually consumed worldwide to increase crop production and land reclamation (Khater, 2008). Studies have shown that heavy metals in fertilizers can accumulate in soil and become readily available to plants (Modaihsh et al., 2004). For some time, there has been serious concern about the simultaneous input of unwanted trace elements, present in the mineral fertilizers, like $\mathrm{Cd}$ and $\mathrm{Cr}$. Therefore, long-term application of fertilizers can redistribute and elevate toxic heavy metals such as $\mathrm{As}, \mathrm{Cd}$ and $\mathrm{Pb}$ in soil and consequently, contribute to increased bioaccumulation of the heavy metals in the food chain.

More than half of the people of Bangladesh are based on agricultural and livestock farming. The poultry and fish sector is an integral part of farming systems and have created both direct and indirect employment opportunity, improved food security and enhanced supply of quality protein to people's meals and reducing poverty level in rural and urban areas of Bangladesh. About $44 \%$ of human daily intake of animal protein comes from livestock and poultry products (HIES, 2010).

The demand for fish, meat and egg has been expanding dramatically with income growth, population growth, urbanization and dietary changes. Recognizing this fact, some immoral feed producer are now using industrial wastes and by-product, especially from tanneries and dying industries, poultry litter to obtain high profit from the poultry and fish feeds. Due to this contamination in feed and food sector, heavy metals enter into our food chain and finally heavy metals are ending up in the food on our plate. Recently, it has been noted that some of the commercial feed producers failed to meet up with standards for the requirement of fish and in many ways, the source of raw material for the production of the feeds tends to be contaminated with heavy metals (Indrajit $e t$ al., 2011). There is very little information on the status of heavy metals in fish and poultry feeds produced by different feed industries, especially, at the local levels. Moreover, mineral supplements are occasionally added to poultry and fish feeds so as to fulfill the requirement. Unfortunately, most of the time, studies conducted on poultry feeds in India, Bangladesh, Pakistan and various other places around the world, have shown the presence of high concentration of heavy metals like $\mathrm{Cr}, \mathrm{Cd}, \mathrm{Pb}, \mathrm{Hg}, \mathrm{Ni}$, etc. purely due to anthropogenic reasons (Mahmood et al., 2004; Hossain et al., 2007; Imran et al., 2014).

The risk associated with the exposure to heavy metals present in foodstuffs represents a concern to human health (Wang and Du, 2013; IARC, 1990; Flora et al., 2012). Hence, in recent years the increasing demand of food safety has accelerated research initiatives regarding the risk associated with consumption of food contaminated by heavy metals (Mansour et al., 2009). So, it has become an urgent issue to analyze the heavy metals in primary produce and raw materials. In Bangladesh, there is very little reliable works have been conducted to analyze the potential health risks from heavy metal contaminated fertilizer and feeds. In this context, the present study aimed to to assess the extent of heavy metal $(\mathrm{Cd}, \mathrm{Cr}$ and $\mathrm{Pb})$ contamination levels in commonly used fertilizer and feeds in the two selected upazilas of Mymensingh a major producer of agricultural and fisheries products.

\section{Materials and Methods}

\subsection{Selection of markets}

Notun Bazar and Mesua Bazar from Mymensingh Sadar upazila; and Pouro Market and Dorirampur Bazar from Trisal upazila were selected for sample collection. These four markets are representative market place for the locations as well as commodities selected.

\subsection{Collection of poultry, fish feed and fertilizer samples}

For this study, fish and poultry feeds and different fertilizer samples were collected from Mymensingh Sadar and Trisal upazillas of Mymensingh district. Equal numbers of fertilizers samples (three for each sample) were collected equally from Mymensingh Sadar and Trisal upazilas. The collected fertilizer samples were TSP, DAP, MoP, gypsum and zinc sulphate. 
Poultry feed samples were collected equally from Mymensingh Sadar and Trisal upazilas. Collected feed samples have the following companies- Quality Feeds Limited, Madina Poultry Feed, United Feeds Ltd. etc. There are many commercial feeds which are being used by the farmers of Mymensingh district for production of fishes. Fish feed samples were collected equally from Mymensingh Sadar and Trisal upazila. Collected feed samples have the following companies - Quality Feeds Ltd., C. P Bangladesh Company Ltd., Fresh Feed, Usha Feeds Limited., Provita Feed Ltd. Etc. Most collected fish feeds were locally produced.

Poultry feed, fish feed and fertilizer samples were finally selected as study samples for the analysis. Six samples of each commodity of poultry feed, fish feed and fertilizer having at least 500g weight were collected from three different vendors in every selected market. Then the samples were kept into air tight zip lock bags. The bags were properly labeled with unique codes. All sampling were done during the month of November 2016 and February 2017.

\subsection{Sample processing}

After collection, the samples were air dried and kept in individual paper bag with proper labeling and oven dried (Model no: KD $400 \mathrm{NUVE}$, Turkey) at $60^{\circ} \mathrm{C}$ for 48 hours until a constant weight was obtained. The dried samples were finely ground by an electric grinder (Model no: IKA A11B). Then the ground samples were kept in polythene zipper bags labeled with specific code number until subsequent analysis.

\subsection{Sample digestion}

Exactly $1 \mathrm{~g}$ of each feed samples was taken into a conical flask. Then $10 \mathrm{ml}$ of di-acid mixture $\left(\mathrm{HNO}_{3}: \mathrm{HClO}_{4}=\right.$ 2:1) was added into the conical flask. The samples were digested at $150^{\circ} \mathrm{C}$ until the white fumes appear. About $2 \mathrm{~mL}$ of $\mathrm{H}_{2} \mathrm{O}_{2}$ was added and heated until the digest became colorless. Then the samples were cooled. After cooling, the samples were filtered through Whatman No. 42 filter paper.

In case of fertilizer samples, exactly $1 \mathrm{~g}$ of sample was taken into a conical flask. Then $50 \mathrm{~mL}$ of $50 \% \mathrm{HCl}(1: 1$ dilution) was added into the sand bath. The samples were digested at $180^{\circ} \mathrm{C}$ in hot plate until the samples reached to about $2 \mathrm{ml}$. Then the samples were cooled. After cooling the samples, the samples were filtered through Whatman No. 42 filter paper to remove unwanted suspended materials.

After filtering both fertilizer and feed samples, the digests were made up to $50 \mathrm{~mL}$ volume by deionized water and kept in labeled air tight polyvinyl bottles. Then the samples were stored in the refrigerator until analysis.

\subsection{Analysis of heavy metals}

Determination of different elements $(\mathrm{Cd}, \mathrm{Cr}$ and $\mathrm{Pb})$ in fertilizer, poultry and fish feed samples was done by using a Flame AAS (Model no: SHIMADZU, AA-7000, Japan). Mono element hollow cathode lamp was employed for the determination of each metal of interest. At first, the AAS was calibrated following the manufacturer's recommendation. The filtered samples were run directly for the determination of heavy metals in the samples. Then, the concentration of the metals in fertilizer, poultry and fish feed samples was recorded directly by AAS.

\subsection{Data compilation and processing}

All data were subjected to analysis of variance (ANOVA) using statistical software MiniTab version 17.0 (MiniTable State College, PA, USA).

\section{Results and Discussion}

\subsection{Heavy metals in poultry feeds}

Collected poultry feed samples were analyzed. They showed variable amount of $\mathrm{Cd}, \mathrm{Cr}$ and $\mathrm{Pb}$. The mean concentration and associated standard deviation of $\mathrm{Cd}, \mathrm{Cr}$ and $\mathrm{Pb}$ in poultry feed samples are presented in Table 1 .

The concentration of $\mathrm{Pb}$ in poultry feed ranged between $0-0.729 \mathrm{mg} \mathrm{kg}^{-1}$ (Figure 1). Statistical analysis by MiniTAB 17 revealed that there was significant difference in $\mathrm{Pb}$ content in poultry feed collected from Mymensingh Sadar and Trisal. The mean $\mathrm{Pb}$ content in feed sample from Mymensingh Sadar was $0.073 \mathrm{mg} \mathrm{kg}$

${ }^{1}$. However, $\mathrm{Pb}$ was not detected from the samples collected from Trisal (Table 1).

The concentration of $\mathrm{Cd}$ in poultry feed ranged between $0-0.023 \mathrm{mg} \mathrm{kg}^{-1}$ (Figure 1). Statistical analysis by MiniTAB 17 revealed that there was significant difference in $\mathrm{Cd}$ content. The mean $\mathrm{Pb}$ content in feed sample from Trisal was $0.008 \mathrm{mg} \mathrm{kg}^{-1}$. However, $\mathrm{Cd}$ was not detected from the samples which were collected from Mymensingh (Table 1). The feed samples collected from the certain locations have $\mathrm{Cr}$ concentration below detectable limit by AAS. 
The results for $\mathrm{Pb}$ and $\mathrm{Cd}$ in obtained in this study were lower than $1.10-7.85 \mathrm{mg} \mathrm{kg}^{-1}$ and 23.2-32.6 mg kg-1 obtained by Okoye et al. (2011) and Mahesar (2010) in their analysis of poultry feeds, respectively. Bukar and Saeed (2014) also found $\mathrm{Pb}$ (ranged from $0.56 \pm 0.26$ to $0.47 \pm 0.13 \mathrm{mg} \mathrm{kg}^{-1}$ ) in poultry feed within the permissible limits while Cd levels (ranged from $2.26 \pm 0.67$ to $1.20 \pm 0.51 \mathrm{mg} \mathrm{kg}^{-1}$ ) in all samples exceeded the permissible limit by regulatory bodies. In the present study, however, $\mathrm{Cd}$ and $\mathrm{Pb}$ in all the poultry feed samples met the heavy metal standards set by EC (2003) (2 and 5 ppm for Cd and Pb, respectively) and NRC (2005) (30 and 10 $\mathrm{ppm}$, respectively) contrasting the results of Jothi et al. (2016) who found higher levels of both $\mathrm{Cr}$ and $\mathrm{Pb}$ where $\mathrm{Pb}$ exceeded the standard set by EC.

\subsection{Heavy metals in fish feed}

Collected fish feed samples were analyzed. They showed variable amount of $\mathrm{Cd}, \mathrm{Cr}$ and $\mathrm{Pb}$. The mean concentration and associated standard deviation of $\mathrm{Cd}, \mathrm{Cr}$ and $\mathrm{Pb}$ in fish feed samples are presented in Table 1 .

The concentration of $\mathrm{Pb}$ in fish feed ranged between $0-446.443 \mathrm{mg} \mathrm{kg}^{-1}$ (Figure 1). Statistical analysis by MiniTAB 17 revealed that there was significant difference in $\mathrm{Pb}$ content in fish feed collected from Mymensingh Sadar and Trisal. The mean $\mathrm{Pb}$ concentration in fish feed was determined in Mymensingh and Trisal were 3.581 and $153.824 \mathrm{mg} \mathrm{kg}^{-1}$, respectively (Table 1 and Figure 1).

The concentration of $\mathrm{Cd}$ in fish feed ranged between $0.0913-0.4566 \mathrm{mg} \mathrm{kg}^{-1}$ (Figure 1). Statistical analysis by MiniTAB 17 revealed that there was no significant difference in $\mathrm{Cd}$ content in fish feed collected from Mymensingh Sadar and Trisal. The mean Cd content in fish feed was determined in Mymensingh and Trisal were 0.1598 and $0.4414 \mathrm{mg} \mathrm{kg}^{-1}$, respectively (Table 1). The feed samples collected from the certain locations have $\mathrm{Cr}$ concentration below detectable limit by AAS.

Table 1. Cadmium, $\mathrm{Cr}$ and Pb contents in different feed samples collected from Sadar and Trisal upazilas of Mymensingh district.

\begin{tabular}{|c|c|c|c|c|c|c|c|}
\hline \multirow{2}{*}{ Items } & \multirow{2}{*}{ Location } & \multicolumn{2}{|c|}{$\mathbf{P b}\left(\mathrm{mg} \mathrm{kg}^{-1}\right)$} & \multicolumn{2}{|c|}{$\operatorname{Cr}\left(\mathrm{mg} \mathrm{kg}^{-1}\right)$} & \multicolumn{2}{|c|}{$\mathrm{Cd}\left(\mathrm{mg} \mathrm{kg}^{-1}\right)$} \\
\hline & & Mean & SD & Mean & SD & Mean & $\mathrm{SD}$ \\
\hline \multirow[b]{2}{*}{ Fish feed } & Trisal & 153.824 & 253.446 & $\mathrm{ND}^{*}$ & - & 0.441 & 0.013 \\
\hline & Mymensingh & 3.581 & 5.583 & $\mathrm{ND}^{*}$ & - & 0.160 & 060 \\
\hline \multirow{2}{*}{ Poultry feed } & Trisal & $\mathrm{ND}^{*}$ & - & $\mathrm{ND}^{*}$ & - & 0.008 & 0.013 \\
\hline & Mymensingh & 0.248 & 0.417 & $\mathrm{ND}^{*}$ & - & $\mathrm{ND}^{*}$ & - \\
\hline \multicolumn{8}{|c|}{ Reference standards } \\
\hline EC (2003) & & $5 \mathrm{ppm}$ & & 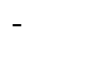 & & & $2 \mathrm{ppm}$ \\
\hline NRC (2005) & & $10 \mathrm{ppm}$ & & & & & $30 \mathrm{ppm}$ \\
\hline
\end{tabular}

*ND- Not detected
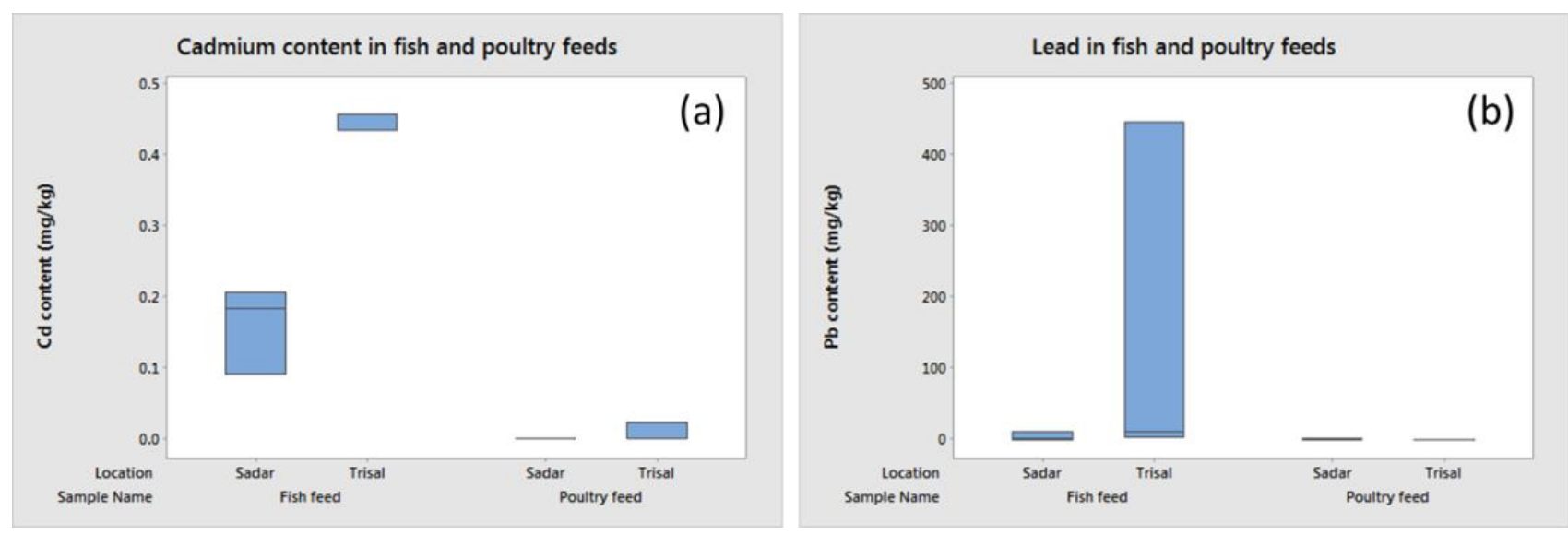

Figure 1. Box plot showing the comparative $\mathrm{Cd}$ (a) and $\mathrm{Pb}$ (b) contents (mean and range) in fish and poultry feeds collected from Mymensingh Sadar and Trisal upazilas.

Here, the fish feed samples from Trisal upazila exceeded the permissible limit set by both EC and NRC. However, Cd levels of all samples were below the international standards. The values of Trisal samples were much higher than that reported by Kundu et al. (2017) (ranged from 7.671 to $12.232 \mathrm{mg} \mathrm{kg}^{-1}$ ) who collected feed samples from Muktagachha Upazila of Mymensingh district. The $\mathrm{Pb}$ content of feed samples from 
Mymensingh Sadar showed more resemblance with the Kundu et al. (2017) result. They also reported higher levels of $\mathrm{Cd}$ in the feed samples (ranged from 8.082 to $9.771 \mathrm{mg} \mathrm{kg}^{-1}$ ) unlike the present study.

\subsection{Heavy metals in fertilizer}

Analysis of heavy metals in five different fertilizers showed variable amount of $\mathrm{Pb}, \mathrm{Cr}$ and $\mathrm{Cd}$. The results are presented in Table 2.

The concentration of $\mathrm{Pb}, \mathrm{Cr}$ and $\mathrm{Cd}$ in DAP fertilizer ranged between $2.16-17.16 \mathrm{mg} \mathrm{kg}^{-1}, 40.59-64.12 \mathrm{mg} \mathrm{kg}^{-1}$ and $0-0.0913 \mathrm{mg} \mathrm{kg}^{-1}$, respectively (Figure 2). Statistical analysis by MiniTAB 17 revealed that except $\mathrm{Pb}$, there was no significant differences in $\mathrm{Cd}$ and $\mathrm{Cr}$ contents in DAP collected from Mymensingh Sadar and Trisal. The mean $\mathrm{Pb}, \mathrm{Cr}$ and $\mathrm{Cd}$ contents in DAP fertilizer from Mymensingh were $12.633,60.392$ and $1.560 \mathrm{mg} \mathrm{kg}^{-1}$, respectively; while in Trisal these were $4.062,54.118$ and $1.781 \mathrm{mg} \mathrm{kg}^{-1}$, respectively (Table 2).

The concentration of $\mathrm{Pb}, \mathrm{Cr}$ and $\mathrm{Cd}$ in TSP fertilizer ranged between $40.73-50.73 \mathrm{mg} \mathrm{kg}^{-1}, 111.765-230 \mathrm{mg} \mathrm{kg}^{-1}$ and $0.776-31.118 \mathrm{mg} \mathrm{kg}^{-1}$, respectively (Figure 2). Statistical analysis by MiniTAB 17 revealed that there was no significant differences in $\mathrm{Pb}, \mathrm{Cd}$ and $\mathrm{Cr}$ contents in TSP collected from Mymensingh Sadar and Trisal. The mean $\mathrm{Pb}, \mathrm{Cr}$ and $\mathrm{Cd}$ contents in TSP fertilizer from Mymensingh were 45.729, 206.667 and $14.749 \mathrm{mg} \mathrm{kg}^{-1}$, respectively; while in Trisal these were 46.919, 168.431 and $15.662 \mathrm{mg} \mathrm{kg}^{-1}$, respectively (Table 2).

Table 2. Cadmium, $\mathrm{Cr}$ and $\mathrm{Pb}$ contents in different fertilizer samples collected from Sadar and Trisal upazilas of Mymensingh district.

\begin{tabular}{|c|c|c|c|c|c|c|c|}
\hline \multirow{2}{*}{ Items } & \multirow{2}{*}{ Location } & \multicolumn{2}{|c|}{$\mathbf{P b}$} & \multicolumn{2}{|c|}{$\mathrm{Cr}$} & \multicolumn{2}{|c|}{ Cd } \\
\hline & & Mean $^{* *}$ & SD & Mean & SD & Mean & SD \\
\hline \multirow{2}{*}{ Gypsum } & Trisal & $21.681 \mathrm{a}$ & 9.101 & 26.863 & 1.891 & 1.180 & 0.765 \\
\hline & Mymensingh & $13.319 b$ & 4.185 & 24.314 & 6.123 & 0.906 & 0.197 \\
\hline \multirow{2}{*}{ MoP } & Trisal & $101.205 \mathrm{a}$ & 70.059 & 16.078 & 0.340 & $3.988 \mathrm{a}$ & 3.369 \\
\hline & Mymensingh & $33.586 b$ & 8.66 & 15.882 & 1.765 & $0.137 b$ & 0.165 \\
\hline \multirow{2}{*}{ TSP } & Trisal & 46.919 & 2.887 & 168.431 & 49.076 & 15.662 & 15.179 \\
\hline & Mymensingh & 45.729 & 5.000 & 206.667 & 28.225 & 14.749 & 1.839 \\
\hline \multirow{2}{*}{$\mathrm{ZnSO}_{4}$} & Trisal & $6.676 b$ & 11.551 & $\mathrm{ND}^{*}$ & - & $3.165 b$ & 0.414 \\
\hline & Mymensingh & $30.014 a$ & 13.906 & $11.373 \mathrm{a}$ & 19.698 & $10.312 \mathrm{a}$ & 7.509 \\
\hline \multirow{2}{*}{ DAP } & Trisal & $4.062 b$ & 1.798 & 54.118 & 12.155 & 1.781 & 1.561 \\
\hline & Mymensingh & $12.633 \mathrm{a}$ & 3.934 & 60.392 & 5.951 & 1.560 & 0.058 \\
\hline
\end{tabular}

*ND- Not detected

** Figures with different letters are significantly different at 5\% levelusing the Tukeymethod.

The concentration of $\mathrm{Pb}, \mathrm{Cr}$ and $\mathrm{Cd}$ in MoP fertilizer ranged between 22.87-157.87 $\mathrm{mg} \mathrm{kg}^{-1}, 14.117-17.647 \mathrm{mg}$ $\mathrm{kg}^{-1}$ and 0-6.874 $\mathrm{mg} \mathrm{kg}^{-1}$, respectively (Figure 2). Statistical analysis by MiniTAB 17 revealed that $\mathrm{Pb}$ and $\mathrm{Cd}$ contents were significantly different in MoP fertilizers collected from Mymensingh Sadar and Trisal. The mean $\mathrm{Pb}, \mathrm{Cr}$ and $\mathrm{Cd}$ contents in MoP fertilizer from Mymensingh were 33.586, 15.882 and $0.137 \mathrm{mg} \mathrm{kg}^{-1}$, respectively; while in Trisal these were $101.205,16.078$ and $3.988 \mathrm{mg} \mathrm{kg}^{-1}$, respectively (Table 2).

The concentration of $\mathrm{Pb}, \mathrm{Cr}$ and $\mathrm{Cd}$ in gypsum fertilizer ranged between $8.557-32.157 \mathrm{mg} \mathrm{kg}^{-1}, 19.412-31.176$ $\mathrm{mg} \mathrm{kg}^{-1}$ and $0.639-2.055 \mathrm{mg} \mathrm{kg}^{-1}$, respectively (Figure 2). Statistical analysis by MiniTAB 17 revealed that except for $\mathrm{Pb}$, no significant differences was found for $\mathrm{Cd}$ and $\mathrm{Cr}$ contents in DAP collected from Mymensingh Sadar and Trisal. The mean $\mathrm{Pb}, \mathrm{Cr}$ and $\mathrm{Cd}$ contents in MoP fertilizer from Mymensingh were 13.319, 24.314 and $0.906 \mathrm{mg} \mathrm{kg}^{-1}$, respectively; while in Trisal these were $21.681,26.863$ and $1.180 \mathrm{mg} \mathrm{kg}^{-1}$, respectively (Table 2).

The concentration of $\mathrm{Pb}, \mathrm{Cr}$ and $\mathrm{Cd}$ in zinc sulphate fertilizer ranged between $0-40.779 \mathrm{mg} \mathrm{kg}^{-1}, 0-34.118 \mathrm{mg}$ $\mathrm{kg}^{-1}$ and $1.644-14.840 \mathrm{mg} \mathrm{kg}^{-1}$, respectively (Figure 2). Statistical analysis by MiniTAB 17 revealed that all three heavy metal contents were significantly different in zinc sulphate fertilizers collected from Mymensingh Sadar and Trisal. The mean $\mathrm{Pb}, \mathrm{Cr}$ and $\mathrm{Cd}$ contents in $\mathrm{MoP}$ fertilizer from Mymensingh were 30.014, 11.373and $10.312 \mathrm{mg} \mathrm{kg}^{-1}$, respectively. In fertilizers collected from Trisal $\mathrm{Cr}$ was below the detection limit. However, $\mathrm{Pb}$ and $\mathrm{Cd}$ contents were 6.676 and $3.165 \mathrm{mg} \mathrm{kg}^{-1}$, respectively (Table 2).

From the results, it was apparent that TSP had the highest contamination of all three metals analysed. The $\mathrm{Pb}$ and $\mathrm{Cd}$ contents in MoP, especially in samples from Trisal, were also high. Among the two sampled locations, except for $\mathrm{Pb}$, little difference was observed considering $\mathrm{Cd}$ and $\mathrm{Cr}$ contents in most fertilizers analysed. However, heavy metal contents vary greatly in zinc sulphate collected from the two locations. Wang and Li 
(2014) systematically reviewed the status of heavy metal contents in chemical fertilizers. Their assessment showed that some phosphate and micronutrient fertilizers, and liming materials contain elevated levels of arsenic, cadmium, and lead compared to other fertilizer types. The results for $\mathrm{Pb}$ contents observed in the present study were much higher than the reports presented by Benson et al. (2014), Atafar et al.(2010) and Sultana (2010) who studied heavy metal load in various NPK fertilizers. On the contrary, Cd levels inthe present study were lower than the values found in same reports.
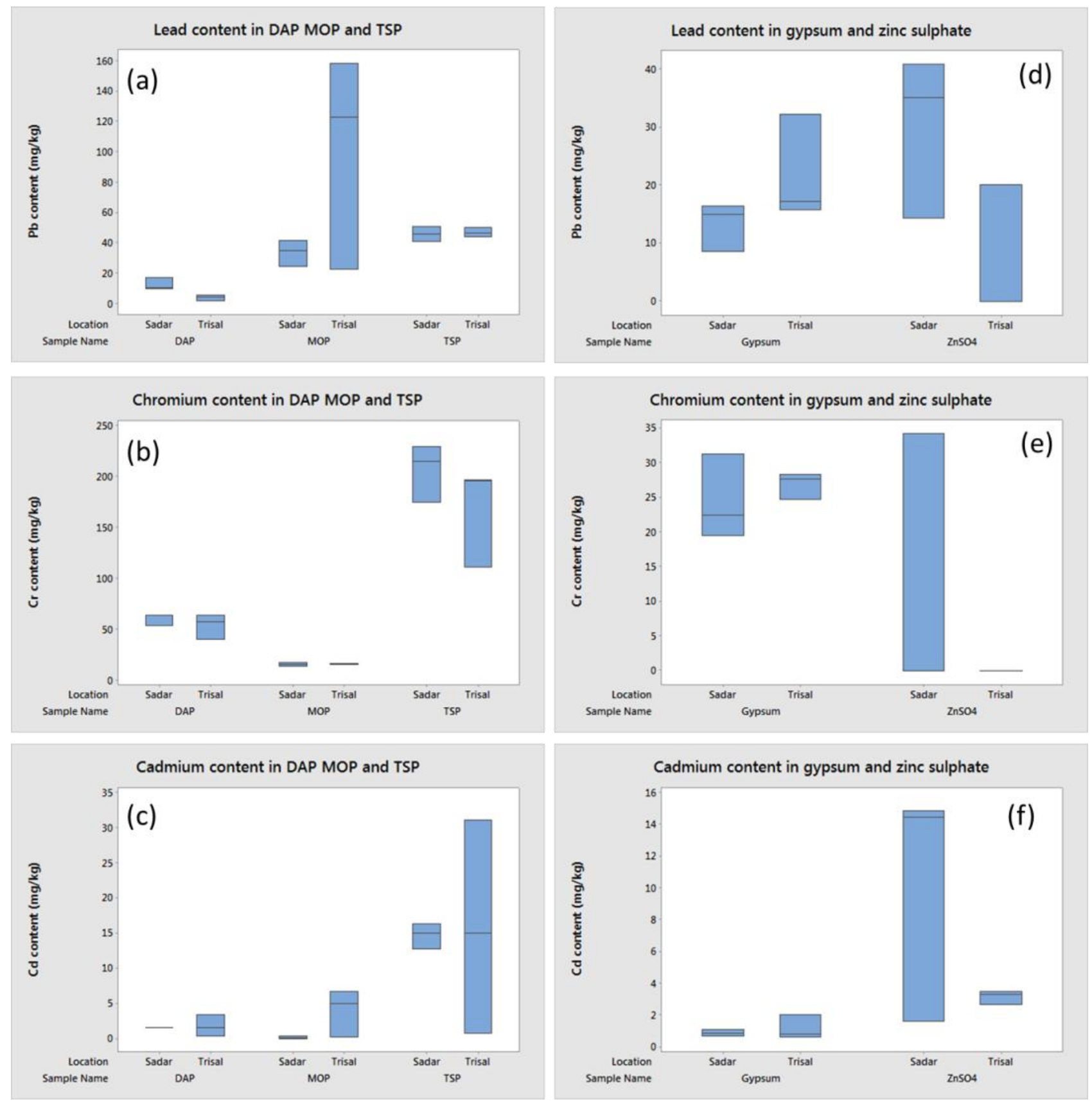

Figure 2. Box plot showing the comparative $\mathrm{Pb}, \mathrm{Cr}$ and $\mathrm{Cd}$ contents (mean and range) in TSP, DAP, MOP (a-c); gypsum and zinc sulphate (d-f) fertilizers collected from Mymensingh Sadar and Trisal upazilas.

\section{Conclusions}

There have been heightened concerns about human health, the environment and the sustainability of farming practices arising from the use of commercial fertilizers as well as animal feeds that contain elevated amounts of toxic trace metals. In this context the research was conducted to assess the heavy metal and trace element concentrations in some fertilizer and feed samples collected from two locations of Mymensingh District. High 
variations in the concentration of heavy metals especially for Pd were found in all samples among the two locations due to the variation in point sources of collection and marketing. Again, no matter how close the sample locations, for some metal elements significant concentration differences were observed in the studied materials. However, the present study has given partial information about contamination status within the study sites but not enough data about the whole country. To understand about the overall contamination status throughout the country, more science based experiment with larger sample size covering all regions should be conducted.

\section{Conflict of interest}

None to declare.

\section{References}

Ali Z, RN Malik and A Qadir, 2013. Heavy metals distribution and risk assessment in soils affected by tannery effluents. Chem. Ecol., 29: 676-692.

Ashraf EM, 2006. Determination of Lead in Environmental Samples using different Radio Analytical Technique. J. Radioanal. Nucl. Chem., 269: 609-619.

Atafar Z, A Mesdaghinia, J Nouri, M Homaee, M Yunesian, M Ahmadimoghaddam and AH Mahvi, 2010. Effect of fertilizer application on soil heavy metal concentration. Environ Monit Assess., 160: 83-89.

Benson NU, UA Winifred and UM Etesin, 2014. Trace metals levels in inorganic fertilizers commercially available in Nigeria. Journal of Scientific Research and Reports, 3: 610-620.

Bukar H and MD Saeed, 2014. Proximate analysis and concentration of some heavy metals in selected poultry feeds in Kano Metropolis, Nigeria. Bayero Journal of Pure and Applied Sciences, 7: 75-79.

EC (European Commission), 2003. Health and Consumer Protection Directorate General, Belgium. Opinion of the Scientific Committee on Animal Nutrition on Undesirable Substances in Feed.

Flora G, D Gupta and ATiwari, 2012. Toxicity of lead: A review with recent updates. Interdisciptoxicol., 5: 4758.

HIES (Household Income and Expenditure Survey), 2010. Bangladesh Bureau of Statistics.

Hossain AMMM, T Monir, AM Rezwan-UlHaque, MAI Kazi, MS Islam and SF Elahi, 2007. Heavy metal concentration in tannery solid wastes used as poultry feed and the ecotoxicological consequences. Bangladesh J. Sci. Ind. Res., 42: 397-416.

IARC (International Agency for Research on Cancer), 1990. Chromium, nickel and welding in IARC monographs on the evaluation of carcinogenic risks to humans. IARC, Lyon, France. vol. 49.

Imran R, A Hamid, R Amjad, CMA Chaudhry, G Yaqub and S Akhtar, 2014. Evaluation of heavy metal concentration in the poultry feeds. J. Bio. \& Env. Sci., 5: 394-404.

Indrajit S, A Shandil and VS Shriastava, 2011. Study of determination of heavy metals in fish species of the River Yamuna (Delhi) by inductively coupled plasma-optical emission spectroscopy (ICP-OES). Adv. Appl. Sci. Res., 2: 161-166.

Jothi JS, N Yeasmin, IZ Anka and S Hashem, 2016. Chromium and lead contamination in commercial poultry feeds of Bangladesh. Int. J. Agril. Res. Innov. \& Tech, 6: 57-60.

Khater AEM, 2008. Uranium and heavy metals in phosphate fertilizers. InUranium, Mining and Hydrogeology. Springer, Berlin Heidelberg, 193-198.

Kundu GK, M Alauddin, MS Akter, MS Khan, MM Islam, G Mondal, D Islam, LC Mohanta and A Huque, 2017. Metal contamination of commercial fish feed and quality aspects of farmed tilapia (Oreochromis niloticus) in Bangladesh. Bioresearch Communications, 3: 345-353.

Mahesar SA, ST Sherazi, A Niaz, MI Bhanger, S Uddin and A Rauf, 2010. Simultaneous assessment of zinc, cadmium, lead and copper in poultry feeds by differential pulse anodic striping voltammetry. Food Chem. Toxicol., 48: 2357-60.

Mahmood NS, AM Ahmad, UI Shumsuddin and AF Khan, 2004. Metal profile of broiler poultry feeds produced in Karachi. J. Chem. Soc. Pak., 26: 97-100.

Mansour SA, MH Belal, AAK Abou-Arab and MF Gad, 2009. Monitoring of pesticides and heavy metals in cucumber fruits produced from different farming systems. Chemosphere, 75: 601-609.

Modaihsh AS, MS Al-Swailem and MO Mahjoub, 2004. Heavy metals content of commercial inorganic fertilizers used in the kingdom of Saudi Arabia. Agricultural and Marine Sciences, 9: 21-25.

Nabulo G, CR Black, J Craigon and SD Young, 2012. Does consumption of leafy vegetables grown in periurban agriculture pose a risk to human health? Environ. Pollut., 162: 389-398. 
NRC (National Research Council), Washington DC, USA, 2005. Mineral Tolerance of Domestic Animals, National Academies Press.

Okoye COB, CN Ibeto and JN Ihedioha, 2011. Assessment of heavy metals in chicken feeds sold in south eastern, Nigeria. Adv. Appl. Sci. Res., 2: 63-68.

Sultana T, 2010. Effect of intensive fertilizer on heavy metal concentration in soils and plants. M.S. Thesis. Department of Soil Science, BAU, Mymensingh.

Wang B and Y Du, 2013. Cadmium and its neurotoxic effects. Oxidative Medicine and Cellular Longevity, Volume 2013, Article ID 898034, 12 pp.

Wang $\mathrm{M}$ and S Li, 2014. Heavy metals in fertilizers and effect of the fertilization on heavy metal accumulation in soils and crops. Journal of Plant Nutrition and Fertilizer, 20: 466-480. 